\title{
Analysis of the Effectiveness of the Policy and Institutional Structures/Mechanisms for Environmental Management in Enugu State, Nigeria
}

\author{
${ }^{1}$ Ettum P. O, ${ }^{2}$ Ikubaiyeje K. P, ${ }^{1 *}$ Okoh T. C, ${ }^{3}$ Umar O. M, and ${ }^{1}$ Ibe J. C \\ ${ }^{1}$ Department of Agricultural Economics, University of Nigeria, Nsukka \\ ${ }^{2}$ Department of Agricultural Extension, Ahmadu Bello University, Kabba Campus, Kogi state \\ ${ }^{3}$ Agro Processing, Productivity Enhancement and Livelihood Improvement Support Project, Lokoja Kogi \\ state, Nigeria
}

\begin{abstract}
Nigeria is rapidly urbanizing and is forecasted to become the 3rd most urbanized nation by 2100. Expectedly, rapid urbanization presents challenges in many areas including the management of municipal services such as solid waste. This yawning failure is reflected in the poor quality of waste services across Nigerian cities. This study focuses on the analysis of the effectiveness of policy and institutional structures/mechanisms for environmental management in Enugu State. The specific objectives are to: identify and analyze the effectiveness of the policies through the performance of the institutions for environmental management and identify the shortcomings of the policies and constraints to the performance of the institutions. Data were generated by a field survey involving the administration of a structured questionnaire. Multistage and Random sampling techniques were used in the selection of three hundred and seventy-eight adult household heads and eleven staff both from the State Ministry of Environment and Mineral Resources and Enugu State Waste Management Authority (ESWAMA). Data were analyzed by descriptive statistics. The result shows that Removal and disposal of waste, vehicles and dead animals, cleaning of streets and sewage clearing and maintenance of disposable equipment where the roles played by ESWAMA; whereas urban sanitation, pollution control and impact assessment were the roles played by the Ministry of Environment and Mineral Resources. Problems identified among the staff against the performance of the institutions include; limitations of the legal framework, institutional bottleneck, corruption, inadequate of EIA, Inadequate of funds and Ignorance. The study recommends the review of the environmental policies and advises that the legal framework should be strengthened for the proper implementation of laws.
\end{abstract}

Keywords: Policy, Environment, Waste Management, Pollution, Effectiveness, Institutional Structures.

\section{INTRODUCTION}

The usefulness of environment is indispensable and cannot be relegated. The inherent environment is an endowment of nature and a main determinant of life on earth. It is made up of four intertwined structures, namely: the air, the water, the land and the habitat (Kumarasamy et al., 2004). It is a cornerstone for human existence and viability as well as provides all the necessary essential of life such as air, water, soil, food, energy, etc (UNDP, 2001). It also provides some essential service amenities such as climate regulation, flood control, natural habitat, and cultural services. In the early days of man the surroundings and its naturalborn resources have rendered important role and continued to play necessary role in social and economic formation of the society. It is the root of universal earnings that must be sustainably guarded and managed. Prior to the evolution of industries, the rate at which our environment was being exploited was low due to low population and inexperience on the various uses of natural resources. The amount of waste generated by the society was small and biodegradable (Okafor, 2011).

But the need to provide man with more quantity and quality of essential goods and services for his survival, led to the concept of industrialization and urbanization. While industrialization give rise to employment opportunity for the jobless, supplies goods and services, increase the rate of urbanization through infrastructural development, it drops along its frontier some negative externalities otherwise known as environmental costs. Pollution is the deliberate or accidental contamination of the environment with waste from human and industrial activities. 
According to J.H. price and French "pollution is the price of progress". They opined that pollution and development are inseparable since pollution is an offshoot of a development process.

The rapid growth of population and unplanned industrialization resulted to the major environmental problems in our society today which include pollution, deforestation, loss of bio-diversity, hazardous chemical and waste, soil erosion, land degradation and depletion of earth's natural resources(UNEP,(2005) and Chong,(2008)) . By 2050, it is projected that China, India and Nigeria would be the world's most populated countries, accounting for $37 \%$ (of the increase of nearly 2.5 billion people in the urban population by 2050) of global urban population. The growing population in Nigeria alone (the most populous African country) is expected to trigger regional concerns in areas of urbanisation, population flows, urban infrastructure and service delivery, food security, resource \& wealth distribution, insecurity/conflicts, and environmental degradation; all of which have the capacity to impact the urban system. To say the least, there will be a significant increase in demand for municipal infrastructure and services delivery. It is therefore, particularly critical to begin to consider the mutually reinforcing fact of political economy and govern ance factors that will continue to affect the financing, provision and delivery of municipal infrastructure and services in Nigerian cities. Currently elsewhere, these factors are receiving increased attention regarding the ways in which they ultimately influence urban infrastructure provision and services delivery. Several empirical studies have been conducted on environmental hazards and the need for planning and control of the Nigeria environment such as flooding (Mba, 1996), biodiversity (Phil-Eze, 2001), soil erosion (Ofomata, 2001) and urban solid waste management (Omuta, 1988, Ajaka, 2001). The environmental problems are inter-related and inter-connected. There are interrelationship between biodiversity loss, desertification, and erosion, loss of soil fertility, diseases outbreaks and climate change (Karen, 1996; Jonathan, 2005; Rao, 2006; Joseph, 2009; Botkin and Keller, 2012).

From the view of Eneh (2007), it is necessary to manage those factors in man's physical environment which impose a dangerous consequence on his physical development, health and survival and this necessitates environmental management.

Since, environmental management aims to preserve the environment and protect its inhabitants from the various environmental hazards, the Nigerian government and several states therein have established different governmental authorities and agencies that would work hand in hand to ensure effective and efficient means of managing the environment at both federal and state level. There are policies and institutional structures/mechanisms put in place for proper management of the environment in the state. The policies, institutional structures and mechanisms include the following; Enugu State Waste Management Authority which has the responsibility to ensure effective and efficient collection, removal, process, treat and safety disposal of domestic, hospital, commercial, institutional and industrial waste and recycling of waste; Ministry of Environment which oversees about cleanness of the state and for monitoring and control of environmental issues; Town Planning Authority, this regulate the structures or type of building/gives approval. Others include; Ministry of Capital Territory, National Youth Service Corps (NYSC) with Partnerships with State Government, National Erosion and Watershed Management Project (NEWMAP), National Environmental Standards and Regulation Enforcement Agency (NESREA) and establishment of Environmental protection court for prosecution of defaulters.

By 2050, it is projected that China, India and Nigeria would be the world's most populated countries, accounting for $37 \%$ (of the increase of nearly 2.5 billion people in the urban population by 2050) of global urban population. The growing population in Nigeria alone (the most populous African country) is expected to trigger regional concerns in areas of urbanization, population flows, urban infrastructure and service delivery, food security, resource \& wealth distribution, insecurity/conflicts, and Environmental degradation; all of which have the capacity to impact the urban system. To say the least, there will be a significant increase in demand for municipal infrastructure such as waste management facilities and services delivery. Recent research has shown that most of these facilities are not available or are in short supply and the Environmental Management Agencies are not discharging their duties effectively despite all government effort at reducing environmental problem did not yield tangible result as environmental problems still persist in every part of Nigeria of which Enugu state is not left out. It is therefore critical to analyze the effectiveness of this policy put in place by government and to also assess the impact of this policy on environmental management in Enugu state. The objectives of this study therefore include;

identify and analyze the effectiveness of the policies through the performance of the institutions for environmental management; identify the short comings of the policies and constraints to the performance of the institutions; and proffer suggestions/remedies towards proper and efficient environmental management

\section{MATERIAL AND METHOD}

The study area is Enugu State, Nigeria. Enugu is a State in Southern Nigeria. The State lies between latitude $5^{\circ} 56^{1} \mathrm{~N}$ and $7^{0} 5^{1} \mathrm{~N}$ of the equator and longitude $6^{\circ} 53^{l} E$ and $7^{0} 55^{1} \mathrm{E}$ of the Greenwich meridian (Anyadike, 2002). The State has land area of about $8,022.95 \mathrm{~km}^{2}$ with seventeen (17) local governments areas (Enugu State Agricultural Development Program) (ENADEP, 2008) and population of about 3,257,298 persons (NPC, 2006). The capital city has a population of 722,664 persons by 2006 census. 
According to National Population Commission (2006) Enugu, the capital of Enugu state is made up of three local government areas namely: Enugu South, Enugu North and Enugu East with a total population of 198,032, 242,050 and 277,119 respectively. The state is predominantly rural and agrarian with about $68 \%$ of its working population engaged in farming, trading (18.8\%) and services (12.9\%) (Williams 2008).

\section{SAMPLING TECHNIQUE}

The first stage involved random selection of two layouts from each local government area.

In the second stage, two (2) streets were purposively selected from each layout making it a total of twelve (12) streets. From each of the streets, thirty two (32) respondents were sampled making a total of three hundred and eighty four (384) respondents. However, out of the three hundred and eighty four (384) questionnaires distributed to the respondents, a total of three hundred and seventy eight (378) of them were effectively filled and returned for analysis. Similarly, eleven (11) questionnaires were also distributed and all returned from eleven management staff of both the State Ministry of Environment and Mineral Resources and Enugu State Waste Management Authority (ESWAMA), making the total number of respondents to be three hundred eighty nine (389). Data for the study were collected through primary and secondary sources using a structured questionnaire. The 378 questionnaires that were returned from adult heads of the households and 11 questionnaires that were returned from both the management staff of Enugu State Waste Management Authority (ESWAMA) and State Ministry of Environment and Mineral Resources was what the researcher used to achieve the objectives of this study.

\section{DATA ANALYSIS}

The objectives of the study were achieved using descriptive statistics. The four-point likert-scale of strongly agree (SA: 4 point), Agree (A: 3 point), Disagree (D: 2 point) and strongly disagree (SD: 1 point) were used. The mean score for each respondent's option was obtained based on the four-point likert scale rating. $4+3+2+1=10 / 4=2.50$. The mean score of the respondents based on the 4- point rating scale was computed as:

$\underline{4+3+2+1}=2.50$

4

\section{RESULT AND DISCUSSION}

Distribution of respondents (general public) according to their response towards the effectiveness of the activities of the institution (ESWAMA)

Table1 shows that the public strongly agreed that ESWAMA collects, removes, processes, treat and safely disposes of waste; remove and disposal of abandoned vehicle; removal and disposal of carcass of animals from public places and design, operate and maintain waste disposal facilities and also agreed that ESWAMA clean streets. Therefore, out of the eight (8) statutory responsibilities of ESWAMA, the general public gave a fair approval that, ESWAMA is effective in number: 1, 2, 3, 5 and 7 as shown in table1.

Table 1 Distribution of respondents (general public) according to their response towards the effectiveness of the activities of the institution (ESWAMA)

\begin{tabular}{|c|c|c|c|c|}
\hline & tatutory Responsibilities & $\mathrm{N}$ & Mean & Decision \\
\hline 1) & $\begin{array}{l}\text { Collect, remove, process, treat and safely disposed } \\
\text { of waste }\end{array}$ & 378 & 3.4101 & Accepted \\
\hline 2) & Clean streets & 378 & 2.5556 & Accepted \\
\hline 3) & Removal and disposal of abandoned vehicle & 378 & 2.6640 & Accepted \\
\hline 4) & Clearing of sewage & & & \\
\hline 5) & Removal and disposal of animals from public places & 378 & 2.0556 & Rejected \\
\hline 6) & $\begin{array}{l}\text { Cleaning, clearing, and maintenance of drainage } \\
\text { system within the state }\end{array}$ & 378 & 2.6303 & Accepted \\
\hline 7) & $\begin{array}{l}\text { Design, operate and maintain waste disposal } \\
\text { facilities }\end{array}$ & 378 & 2.1323 & Rejected \\
\hline \multirow[t]{2}{*}{ 8) } & $\begin{array}{l}\text { Control and keep close watch on all waste disposed } \\
\text { system in the state }\end{array}$ & 378 & 2.8519 & Accepted \\
\hline & & 378 & 2.3228 & Rejected \\
\hline
\end{tabular}


Distribution of respondents (general public) according to their response towards the effectiveness of the activities of the Ministry of Environment and Mineral Resources

The table 2 shows that the public agreed that the institution is effective in Urban sanitation and beautification, pollution control, and in setting guide lines for environmental impact assessment (EIA) with mean score of 2.6640, 2.6217 and 2.5079 respectively and ineffective in others as indicated in the table below:

Table 2 Distribution of respondents (general public) according to their response towards the effectiveness of the activities of the Ministry of Environment and Mineral Resources

\begin{tabular}{lllll}
\hline \multicolumn{2}{c}{ Statutory Responsibilities } & N & Mean & Decision \\
\hline 1) & Soil erosion control & 378 & 2.4868 & Rejected \\
2) & Urban sanitation and beautification & 378 & 2.6640 & Accepted \\
3) & Pollution control & 378 & 2.6217 & Accepted \\
4) & Urban sewage management and control & 378 & 2.1958 & Rejected \\
5) & Setting guidance for fumigation of premises & 378 & 2.1534 & Rejected \\
$6)$ & Mitigation of climate change & 378 & 1.9180 & Rejected \\
$7)$ & Regulation of outdoor advertisement & 378 & 2.0450 & Rejected \\
$8)$ & Set guidelines for environment impact assessment (EIA) & 378 & 2.5079 & Accepted \\
$9)$ & Supervise the activities of the forestry commission & & 2.1005 & Rejected \\
$10)$ & Provide regulatory scheme for environmental protection & 378 & & Rejected \\
& and conservation & 378 & 2.1243 & Rejected \\
\hline
\end{tabular}

Valid N

378

Distribution of respondents (management staff) according to their response on constraints to the performance of the institutions

The table 3 depicts that limitations of legal framework, institutional bottleneck, corruption, inadequacy of environmental impact assessment, inadequacy of funding and ignorance were major constraints affecting the performance of the institutions. It can be deduced that, without all these put in appropriate place at the appropriate time, the institutions cannot function effectively. Others are lack of working tools to carry out their duties very effective, Government interference when a high profile person default, Poor sensitization program and lack of basic infrastructures like access road to dump site by waste evacuation trucks

Table 3 Distribution of respondents (management staff) according to their response on constraints to the performance of the institutions

\begin{tabular}{lllll}
\hline \multicolumn{2}{l}{ Constraints } & $\mathrm{N}$ & $\mathrm{Mean}$ & Decision \\
\hline 1$)$ & Limitations of legal framework & 11 & 3.4545 & Accepted \\
$2)$ & Institutional bottleneck & 11 & 3.0909 & Accepted \\
$3)$ & Corruption & 11 & 3.1818 & Accepted \\
$4)$ & Inadequacy of EIA & 11 & 2.9091 & Accepted \\
$5)$ & Inadequacy of funding & 11 & 3.3636 & Accepted \\
$6)$ & Ignorance & 11 & 3.1818 & Accepted \\
\hline \multicolumn{2}{l}{ Valid N } & & & \\
\hline
\end{tabular}

\section{CONCLUSION}

This study reveals the situation analysis of environmental policies and the institutional structures/mechanisms put in place for environmental management. It shows that the environmental policies were not followed and implemented to the latter. It also shows that the performance of the institutions were below average. These were attributed to the constraints faced by the 
institutions. Therefore, this study recommends that the existing legal provisions should be reviewed and strengthened to accommodate and control the enormous problem of the environment caused by the human activities.

\section{REFERENCES}

Ajaka Dike. J(2001) Urban Solid Waste: Problems and Management in Nigeria, in Ofomata GEK and Phil-Eze P.O. in Geographical Perspectives on Environmental Problems and Management in Nigeria, Enugu, pp164-181

Aluko. O (2001): Environmental Pollution and Waste Management (ed) Ola Aluko in Introductory Course in Environmental Sciences; pg43-59. Ibadan: Odunprints.

Anyadike, R,N.(2002). Climate and Vegetation in : G.E.K Offormata (eds) . A Survey of the Igbo Nation, Onitsha; Africa First Publisher Limited

Chong, R.R(2008) Determinant of Bank Profitability in a Developing Economy: Empirical Evidence from Philippians. Asian Academy of Management Journal of Accounting and

Enugu State Government Official Gazette (2017). An Official Gazette Published on the Web by

Hamid, A.A, Usman, L.A., Elaigwu, S.E and Zubair, .F(2010). Environmental and Health Risk of Bush Burning. Advances in Environmental Biology, 6Nigr (27), 042, 963

Jonathan, M.H(2006). Environmental and Natural Resources Economics. Boston: Houghton Mifflin Company.

Joseph, B. (2009). Environmental Studies (2 ${ }^{\text {nd }}$ ed.) New Delhi: Mcgraw-Hill

Kumarasamy et al (2004) Constructional Industry Development: Journal of Sustainable Environment-Chapter One.

Offormata, B.A (1998)"Land Degradation in South Eastern Nigeria”, Journal of Applied Social Science, vol1 no pp5-14.

Ogrigiri, M.A(1990) "Controlling the Threat and Menace of Desertification and Erosion in Nigeria" in the Environment and Sustainable Development in Nigeria Proceedings of a Workshop Held at the Nicon Nogahilton Hotel, Abuja FCT. $25^{\mathrm{TH}}-$ $26^{\mathrm{TH}}$, April, 1989. Federal Environmental Protection Agency.

Okafor, (2011) Population Distribution in Nigeria, Johnson Press Ltd, Enugu.

Omuta, G.C.D (1988) Urban Solid Waste Generation and Management: Towards an Environmental Sanitation Policy in Sada P.O and Odemerh F.O (OPcit), pp77-87

Phil Eze (2001), Biodiversity and Environmental Problems in Nigeria in Ofomata G.E.K and Phil. Eze P.O (op cit), Enugu pp 3352

ROA, C.S (2006). Environtmental Pollution and Control and Engineering, New Delli: Age International Limited.

UNEP(2005). Environment Retrieved 15 January 2005 from http://www.grida.no/climate/vital/03.htm.

UNEP (United Nations Environment Programme) (2005) Solid Waste Management. Vol.1

Williams, L. (2008). The Bradt Travel Guide. Bradt Travel Guides. Pp. 196.

\section{*Correspondence: timothynonsookoh@gmail.com}




\section{APPENDIX}

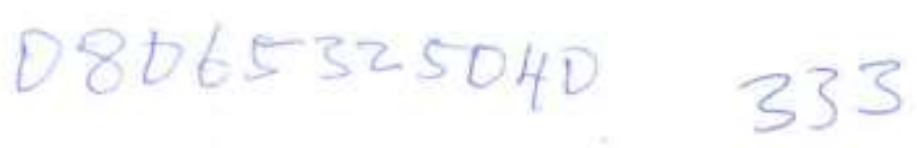

Section A: Personal Data.

Please tick in $(\sqrt{ })$ the appropriate column that gives true information about you

Sex: Male $\square \quad$ Female $\square$

Marital Status: Single $\square$ Married $\square$

Age: Below 20 yrs $\square \quad 21-41 \quad \square \quad 42-65 \square$

Occupation: Traders $\square$ Farmers $\square$ Workers $\square$ Students

others

Academic level: Primary $\square$ Secondary $\square$ Degree $\square$

Postgraduate

No formal education

Religion: Christianity $\square$ Muslim $\square$ Traditional $\square$ others

Length of service: $0-1 \quad \square \quad \begin{array}{ll}1-2 \\ \square\end{array} \quad 3-4 \square \quad 6-7 \square$

Section B: Environmental Problems in the state

$$
\begin{aligned}
& \mathrm{SA}=\text { Strongly Agree } \\
& \mathrm{A}=\text { Agree } \\
& \mathrm{D}=\text { Disagree } \\
& \mathrm{SD}=\text { Strongly Disagree }
\end{aligned}
$$

\begin{tabular}{|c|c|c|c|c|}
\hline Environmental problems & SA & A & $\bar{D}$ & SD \\
\hline Air pollution & & & $\checkmark$ & \\
\hline Indiscriminate dumping of refuse & & $\checkmark$ & & \\
\hline overcrowding & & & $\checkmark$ & \\
\hline Poor urban housing & & $\checkmark$ & & \\
\hline Noise pollution & & 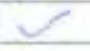 & w & \\
\hline Water pollution & & & $\checkmark$ & \\
\hline Land/Soil pollution & & & $\checkmark$ & \\
\hline Biodiversity loss & & & $\checkmark$ & \\
\hline Deforestation & & $\checkmark$ & & \\
\hline Erosion/flood & & & $V$ & \\
\hline High density of motor & & 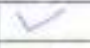 & & \\
\hline Vehicle & & V & & \\
\hline
\end{tabular}

(please, tick $(\downarrow)$ as many as are applicable 
Others specify.

SECTION C: Examine the effectiveness of the policies for environmental management through the performance of the institution with regards to their statutory responsibilities.

i. Enugu State Waste Management Authority (ESWAMA) Statutory responsibilities

\begin{tabular}{|l|l|l|l|l|}
\hline performance & SA & A & D & SD \\
\hline $\begin{array}{l}\text { Collect, Remove, Process, Treat and safely } \\
\text { disposed of waste }\end{array}$ & & $\checkmark$ & & \\
\hline $\begin{array}{l}\text { Clean streets } \\
\text { Removal and disposal of abandoned vehicle }\end{array}$ & & & & \\
\hline $\begin{array}{l}\text { Clearing of sewage } \\
\text { Removal and disposal of carcass of animals } \\
\text { from public places }\end{array}$ & & & $\checkmark$ & \\
\hline $\begin{array}{l}\text { Cleaning, clearing and maintenance of } \\
\text { drainage system within the state }\end{array}$ & & $\checkmark$ & & \\
\hline $\begin{array}{l}\text { Design, operate and maintain waste disposal } \\
\text { facilities }\end{array}$ & & $\checkmark$ & & \\
\hline $\begin{array}{l}\text { Control and keep close watch on all waste } \\
\text { disposed system in the state }\end{array}$ & & & & \\
\hline
\end{tabular}

ii. State Ministry of Environment and Mineral Resources

\begin{tabular}{|l|l|l|l|l|}
\hline performance & SA & A & D & SD \\
\hline Soil Erosion control & & & & \\
\hline Urban Sanitation and Beautification & & & & \\
\hline Pollution control & & & & \\
\hline Urban sewage management and control & & & & \\
\hline Setting guidance for fumigation of premises & & & & \\
\hline Mitigation of climate change & & & & \\
\hline Regulation of outdoor advertisernent & & & & \\
\hline $\begin{array}{l}\text { Set guidelines for environmental impact } \\
\text { assessment }\end{array}$ & & & & \\
\hline $\begin{array}{l}\text { Supervise the activities of the forestry } \\
\text { commission }\end{array}$ & & & & \\
\hline $\begin{array}{l}\text { Provide regulatory scheme for environmental } \\
\text { protection and conservation }\end{array}$ & & & & \\
\hline Sensitization & & & $\checkmark$ & \\
\hline
\end{tabular}


Section A: Personal Data

\section{2}

Please tick in $(\checkmark)$ the appropriate column that gives true information about you

Sex: Male $V$ Female $\square$

Marital Status: Single $\square$ Married $\square$

Age: Below 20 yrs $\square \quad 21-41 \quad \square \quad 42-65 \square$

Occupation: Traders $\square$ Farmers $\square$ Workers $\square$ Students $\square$ others

Academic level: Primary $\square$ Secondary $\square$ Degree $\square$ Postgraduate

V

No formal education

Religion: Christianity $\vee$ Muslim

Length of service: $0-1$

$1-2$

Traditional others

Section B: Environmental Problems in the state.
$\mathrm{SA}=$ Strongly Agree
A $=$ Agree
D = Disagree
$\mathrm{SD}=$ Strongly Disagree

(please, tick $(\sqrt{ })$ as many as are applicable

\begin{tabular}{|l|l|l|l|l|}
\hline Environmental problems & SA & A & D & SD \\
\hline Air pollution & & L & & \\
\hline Indiscriminate dumping of refuse & & & & \\
\hline overcrowding & & & & \\
\hline Poor urban housing & & & & \\
\hline Noise pollution & & & & \\
\hline Water pollution & & & & \\
\hline Land/Soil pollution & & & & \\
\hline Biodiversity loss & & & & \\
\hline Deforestation & & & & \\
\hline Erosion/flood & & & & \\
\hline High density of motor & & \\
\hline Vehicle & & \\
\hline
\end{tabular}


International Journal of Research in Agriculture, Biology \& Environment (ijagri), Vol. 2 (4), Oct -Dec - 2021

2. What are the expected outcomes of the policies?

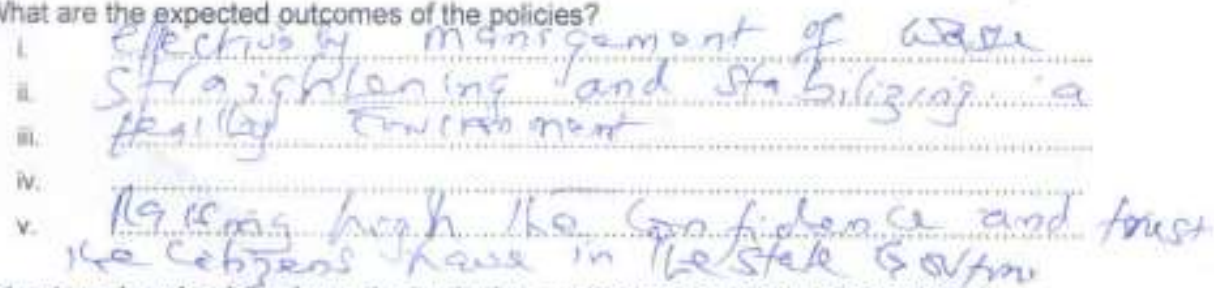

3. What structures/mechanisms have the institution put in place to achieve the policies?

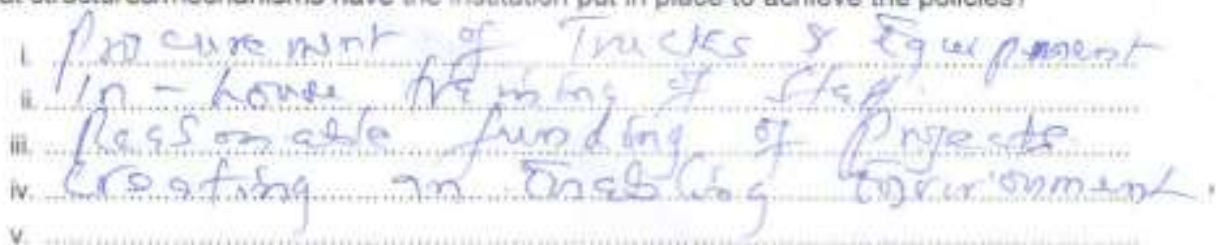

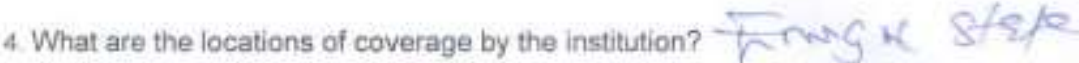

5. What are the shortcomings of the policies?

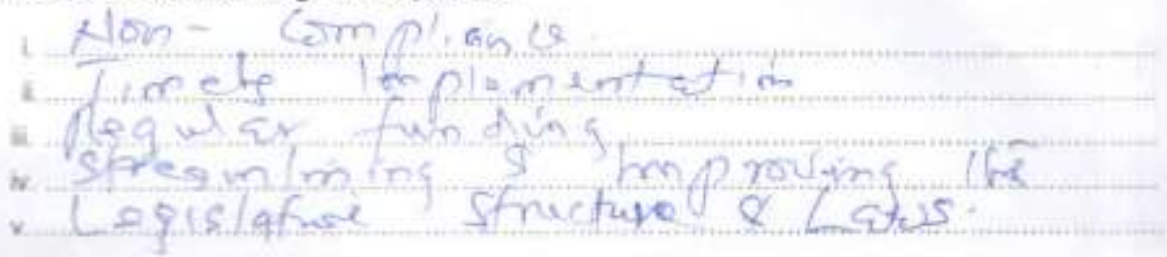

6. What challenges does the institution encounter in order to achieve the policies?

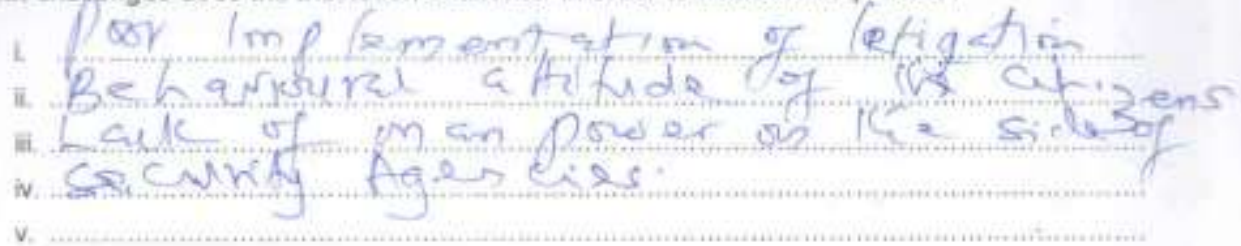

7. How was the institution found? $2 . y$ hanso

SECTION D: Shortcomings of the policies and constrains to the performance of institution for environmental managernent.

\begin{tabular}{|l|l|l|l|l|}
\hline & SA & A & D & SD \\
\hline Limitations of legal frame work & & & & \\
\hline Institutional bottleneck & & & & \\
\hline Corruption & & & & \\
\hline Inadequacy of Environmental Impact Assessment & & & \\
\hline Inadequacy of funding & & V & & \\
\hline Ignorance & & \\
\hline
\end{tabular}

Others specify: 
International Journal of Research in Agriculture, Biology \& Environment (ijagri), Vol. 2 (4), Oct -Dec - 2021

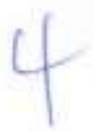

Section A: Pessonal Date

Please to in $(v)$ the appropriate column that gives true information about you

Sex: Wale

Female

Maritai Status Single $\square$ Married $\square$

Age: Below 20 yrs $\square 21-41 \square 42-65$

Occupation: Traders $\square$ Farmers

Workers $\square$ Students

others

Academic level: Primary

Secondary

Degree $\square$ Postgraduate

No formal education

Religion: Christianity Muslim

Traditional

Length of service: $0-1$

$1-2$

6.7

Section B: Environmental Problems in the state.
$S A=$ Strongly Agree
$A=$ Agree
D $=$ Disagree
SD $=$ Strongly Disagree

(please, tick ( $V$ ) as many as are applicable

\begin{tabular}{|c|c|c|c|c|}
\hline Environmental problems & SA & A & $\mathrm{D}$ & SD \\
\hline Air pollution & & $\checkmark$ & $\sqrt{ }$ & \\
\hline Indiscriminate dumping of refuse & & & $\gamma$ & \\
\hline overcrowding & & & $\checkmark$ & E \\
\hline Poor urban housing & & & & $\checkmark$ \\
\hline Noise pollution & & & & 2 \\
\hline Water pollution & & & & $\checkmark$ \\
\hline Land/Sol pollution & & & & $\checkmark$ \\
\hline Biodiversity loss & & & & 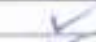 \\
\hline Deforestation & & & & $k$ \\
\hline Erosioniflood & & 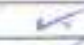 & & \\
\hline High density of motor & & $\sqrt{2}$ & & \\
\hline Vehicie & & $r$ & & \\
\hline
\end{tabular}

SECTION C: Identify and describe the various policies and institutional structures/mechanisms in place for environmental management in the state

1. What policieg is thiq institution pased upon? tity fuctors ellectecfor

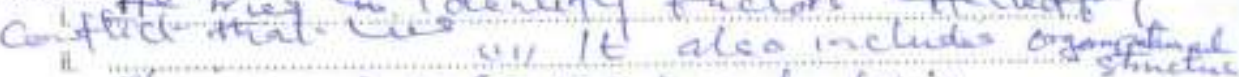
ii. Planme and reSouces for devalepi:

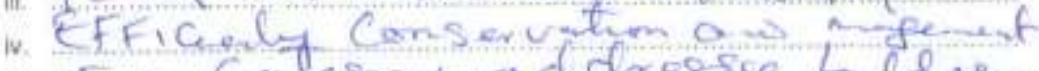

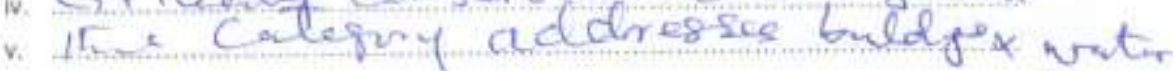
way 
International Journal of Research in Agriculture, Biology \& Environment (ijagri), Vol. 2 (4), Oct -Dec - 2021

2. What are the expected outcomes of the pglicies?

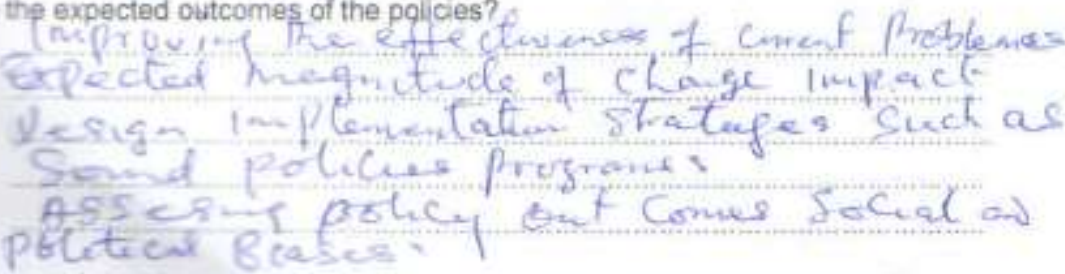

3. What structures/mechanisms have the institution put in place to achieve the policies?

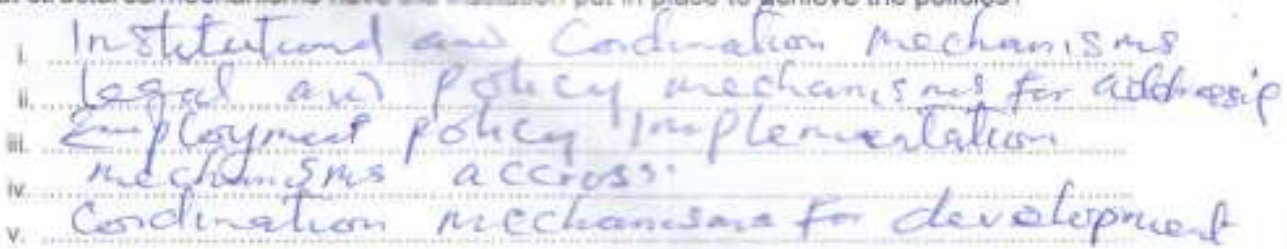

4. What are the locations of coverage by the institution?

5. What are the shortcomings of the policies?

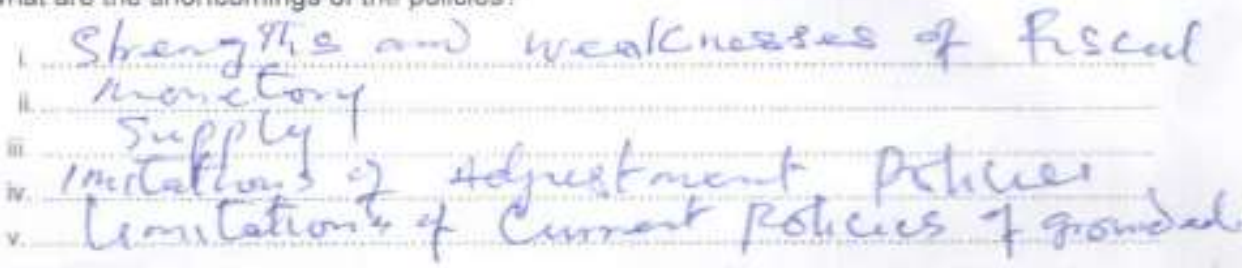

6. What challenges does the institution encounter in order to achieve the policies?

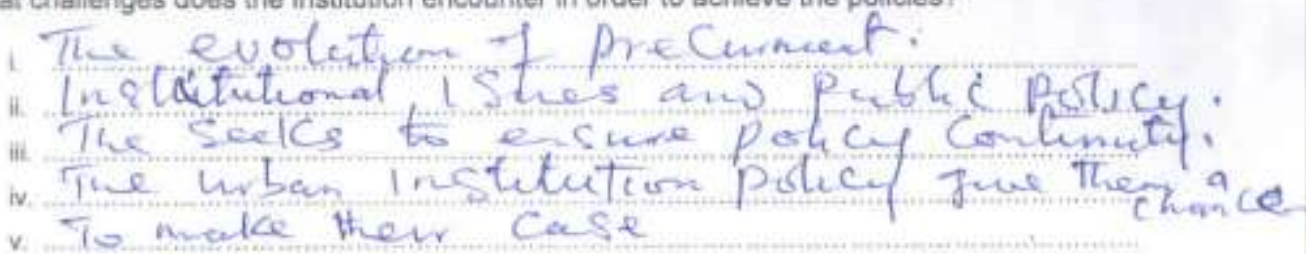

7. How was the institution found?

SECTION D: Shortoomings of the policies and constrains to the performance of institution for environmental management.

\begin{tabular}{|l|l|l|l|l|}
\hline & SA & A & D & SD \\
\hline Limitations of legal frame work & & & & \\
\hline Institutional bottieneck & & & & \\
\hline Corruption & & & & \\
\hline Inadequacy of Environmental impact Assessment & & $\checkmark$ & & \\
\hline Inadequacy of funding & & - & & \\
\hline Ignorance & $\checkmark$ & & & \\
\hline
\end{tabular}

Others specify 
International Journal of Research in Agriculture, Biology \& Environment (ijagri), Vol. 2 (4), Oct -Dec - 2021

Soction A: Persona! Data

Piease tick in $(\sqrt{ })$ the appropriate column that gives true information about you

Sex: Male

$\square$ Female

Marital Status: Single

$\square$ Married

Age: Below 20 yrs

$21-41 \square 42-65$

Occupation: Traders

Farmers

Workers

Students

others

Academic level: Primary

Secondary

Degree

2 Postgraduate

No formal education

Religion: Christianity $\checkmark$ Muslim

Traditional $\square$ others

Length of service: $0-1$

Section B: Environmental Problems in the state

$\mathrm{SA}=$ Strongly Agree
$\mathrm{A}=$ Agree
$\mathrm{D}=$ Disagree
$\mathrm{SD}=$ Strongly Disagree

(please, tick $(v)$ as many as are applicable

\begin{tabular}{|c|c|c|c|c|}
\hline Environmental problems & SA & $\bar{A}$ & D & SD \\
\hline Air pollution & & 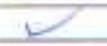 & & \\
\hline Indiscriminate dumping of refuse & & & 2 & \\
\hline overcrowding & & & $\checkmark$ & \\
\hline Poor urban housing & & & & 2 \\
\hline Noise pollution & & & & 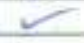 \\
\hline Water pollution & & & & w \\
\hline Land/Soil pollution & & & & $\sim$ \\
\hline Biodiversity loss & & & & $\zeta$ \\
\hline Deforestation & & $=$ & & $\kappa$ \\
\hline Erosionflood & & & $<$ & \\
\hline High density of motor & & v & & \\
\hline Vehicle & & W & & \\
\hline
\end{tabular}

SECTION C: Identify and describe the various policles and institutional structures/mechanisms in place for environmental management in the state

1. What policies is this institution based upon?

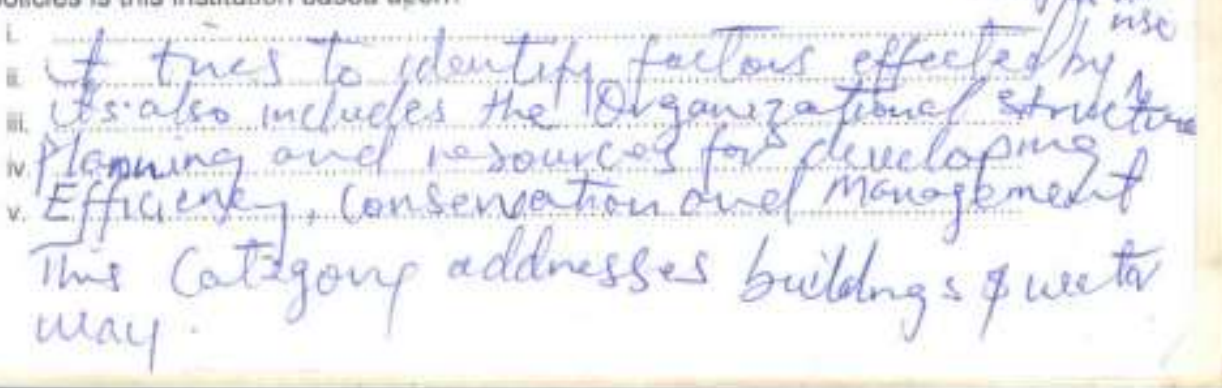


2. What are the expected outcomes of the policies?

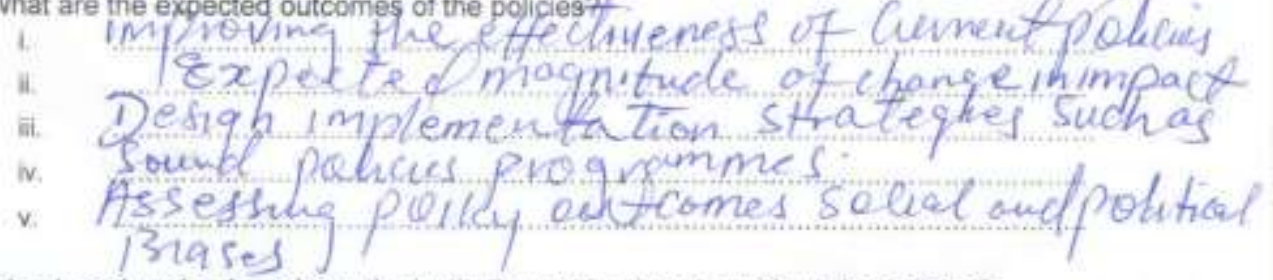

3. What structures/mechanisms have the institution put in place to achieve the policies?

Institutiongl and Coydinalion mechawisms

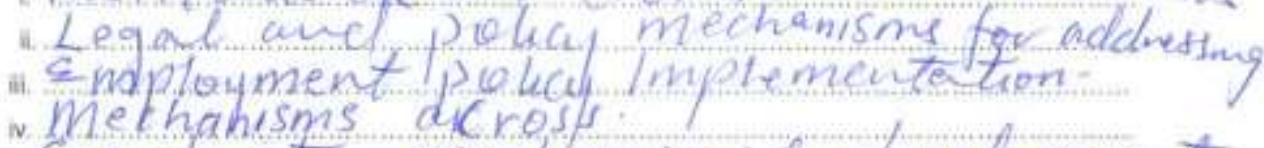

ve Cordination Mechanims fa cleuelopment

4. What are the locations of coverage by the institution?

5. What are the shortcomings of the policies?

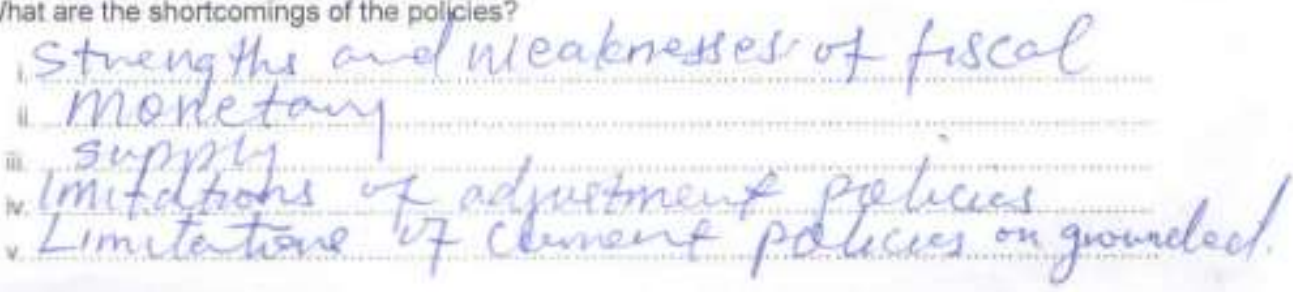

6. What challenges does the institution encounter in order to achieve the policies?

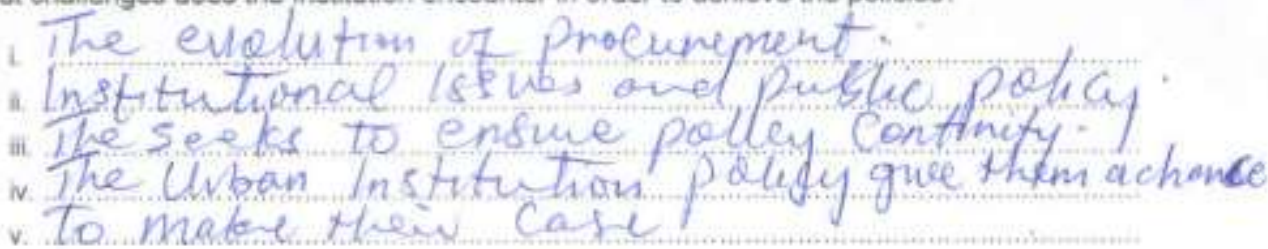

7. How was the institution found?

SECTION D: Shortcomings of the policies and constrains to the performance of institution for environmental management.

\begin{tabular}{|l|l|l|l|l|}
\hline & SA & A & D & SD \\
\hline Limitations of legal frame work & & - & & \\
\hline Institutional bottleneck & & & & \\
\hline Corruption & & & & \\
\hline Inadequacy of Environmental impact Assessment & & & & \\
\hline Inadequacy of funding & & & & \\
\hline Ignorance & & & & \\
\hline
\end{tabular}

Others specity 
International Journal of Research in Agriculture, Biology \& Environment (ijagri), Vol. 2 (4), Oct -Dec - 2021

Section A: Personal Data

Please tick in $(v)$ the appropriate colum that gives true information about you

Sex: Male $\square$ Female

Marital Status: Single $\square$ Married $\square$

Age: Below 20 yrs $\square 21-41 \quad \square \quad 42-65$

Occupation: Traders $\square$ Farmers $\square$ Workers $\square$

stme livel of hutependo-a

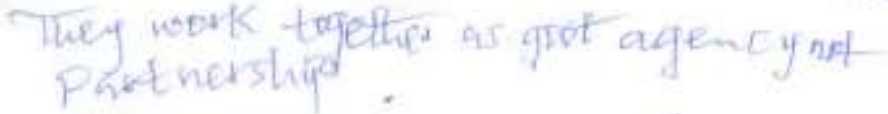
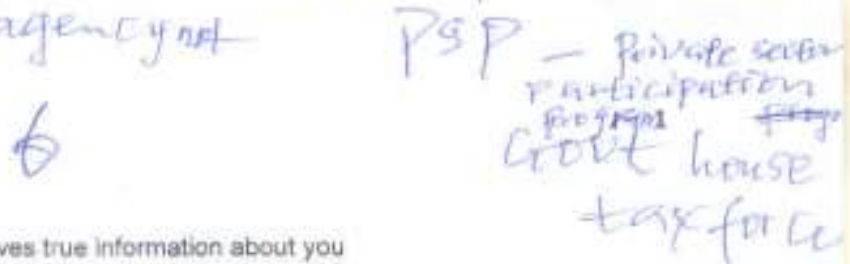

Academic level: Primary

Secondary

Degree

Students

others

No formal education

Religion: Christianity

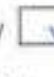

Muslim

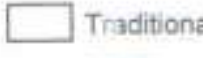

Length of service: $0-1$

1.2

$3-4$

$6=7$

Section B: Environmental Problems in the state

$$
\begin{aligned}
& \mathrm{SA}=\text { Strongly Agree } \\
& \mathrm{A}=\text { Agree } \\
& \mathrm{D}=\text { Disagree } \\
& \mathrm{SD}=\text { Strongly Disagree }
\end{aligned}
$$

(please, tick ( $(v)$ as many as are applicable

\begin{tabular}{|l|l|l|l|l|}
\hline Environmental problems & SA & A & D & SD \\
\hline Air pollution & & & & \\
\hline Indiscriminate dumping of refuse & & & & \\
\hline overcrowding & & & & \\
\hline Poor urban housing & & & & \\
\hline Noise pollution & & & & \\
\hline Water pollution & & & & \\
\hline Land/Soil pollution & & & & \\
\hline Biodiversity loss & & & & \\
\hline Deforestation & & & & \\
\hline Erosion/flood & & & & \\
\hline High density of motor & & & \\
\hline Vehicle & & & \\
\hline Others specify & & & \\
\hline
\end{tabular}

SECTION C: Identify and describe the various policies and institutional structuresimechanisms in place for environmental management in the state.

1. What policies is this institution besed upon?

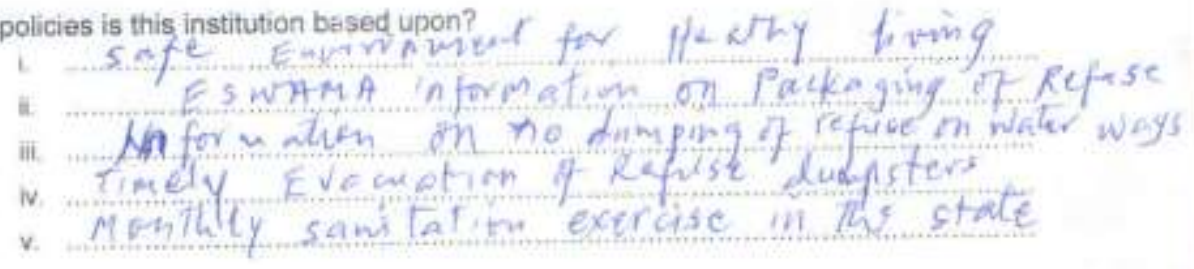


International Journal of Research in Agriculture, Biology \& Environment (ijagri), Vol. 2 (4), Oct -Dec - 2021

2. What are the expected outcomes of the policies?

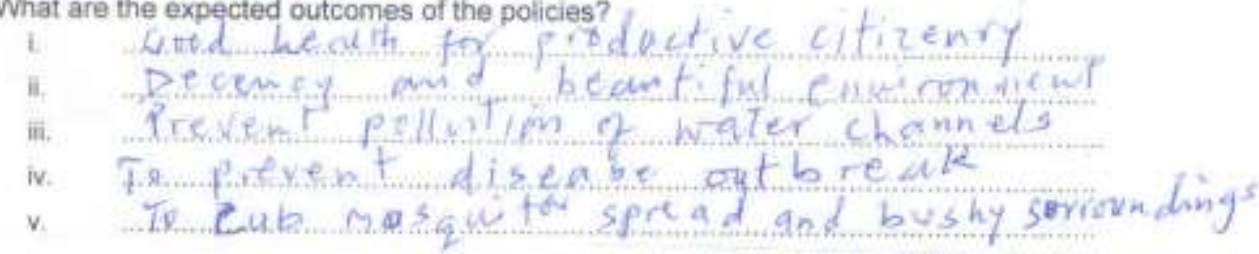

3. What structures/mechanisms have the institution put in place to achieve the policies?

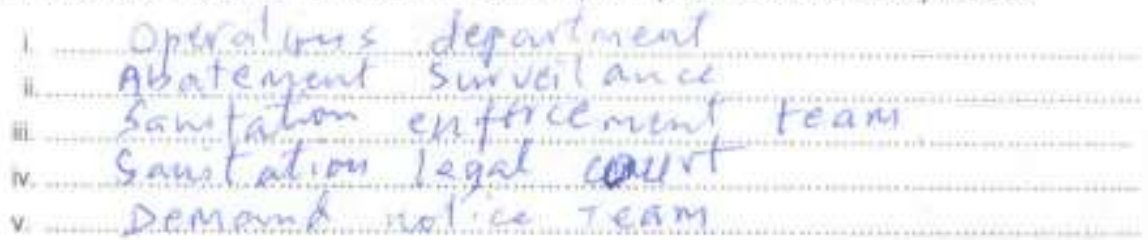

4. What are the locations of coverage by the institution? Enuqu wrban, Nswka

5. What are the shortcomings of the policies?

urban, Aybitw, obDlle and orit Rivet

i. Grownded and Non-operatumal tiplert and Truke

i. Alo function $\mathrm{H}$ Hiluz es avmlate

iii... Por mobi $L_{2}$ ation of ctoff

iv Prtitial interfencues in the functions $n$ EswilenA

v. A sorsety that ned conpulgion rafhes than lostruction

6. What challenges does the institution encounter in order to achieve the policies?

- Government retpongerbilities to Eswama support is lockory

ii Enforcemant 5 a a f are somenstiongh beaten up in the firld

iii. Monetory acterty expendive is not enwiogh

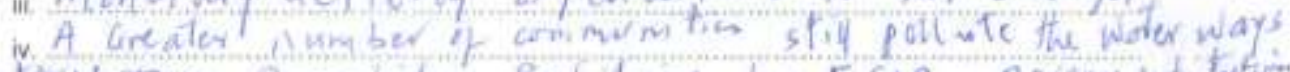

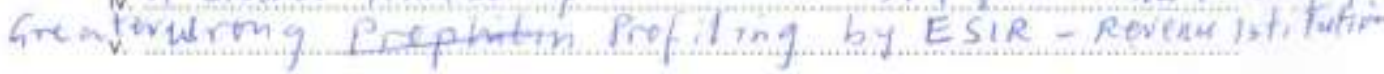

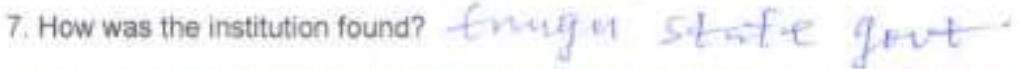

SECTION D: Shortcomings of the policies and constrains to the performance of institution for environmental management.

\begin{tabular}{|l|l|l|l|l|}
\hline & SA & A & D & SD \\
\hline Limitations of legal frame work & & & & \\
\hline Institutional bottieneck & & & & \\
\hline Corruption & & $\checkmark$ & & \\
\hline Inadequacy of Environmental impact Assessment & & V & & \\
\hline Inadequacy of funding & & & & \\
\hline Ignorance & & & \\
\hline
\end{tabular}

Others specify 
International Journal of Research in Agriculture, Biology \& Environment (ijagri), Vol. 2 (4), Oct -Dec - 2021

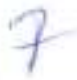

Section A: Personal Data

Please tick in $(v)$ the appropriate column that gives true information about you

Sex: Male $\square$ Female $\square$

Marital Status: Single $\square$ Married

Age: Below 20 yrs $\square 21-41 \square 42-65$

Occupation: Traders $\square$ Farmers $\square$ Warkers $\square$ Students 4 others 5

Academic level: Primary $\square$ Secondary $[12$ Degree $[6]$ Postgraduate $\square$ is

No formal education

Religion: Christianity

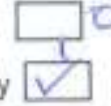

Length of service; $0-1$

Muslim
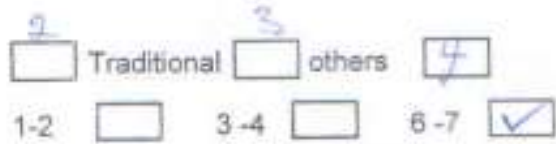

Section B: Environmental Problems in the state

$\mathrm{SA}=$ Strongly Agree $\checkmark$
$\mathrm{A}=$ Agree
$\mathrm{D}=$ Disagree
$\mathrm{SD}=$ Strongly Disagree

(please, tick $(\sqrt{ })$ as many as are applicable

\begin{tabular}{|c|c|c|c|c|}
\hline Environmental problems. & SA & A & 0 & SD \\
\hline Air pollution & $V$ & & & \\
\hline Indiscriminate dumping of refuse & & & $\checkmark$ & \\
\hline overcrowding & & & & $\checkmark$ \\
\hline Poor urban housing & & & $V$ & \\
\hline Noise pollution & $V$ & & & \\
\hline Water pollution & & $\checkmark$ & & \\
\hline Land/Soil pollution & & $\checkmark$ & & \\
\hline Biodiversity loss & $\checkmark$ & & & \\
\hline Deforestation & $\checkmark$ & & & \\
\hline Erosion/flood & & $V$ & & \\
\hline High density of motor & & $V^{\prime}$ & & \\
\hline Vehicie & & $\checkmark$ & & \\
\hline
\end{tabular}

Others specify

SECTION C: Identify and describe the various policies and institutional structures/mechanisms in place for environmental management in the state

1. What policies is this institution based upon?

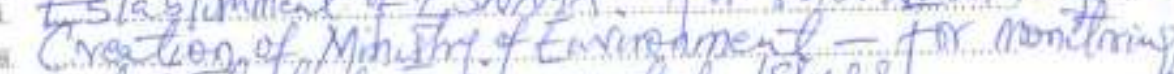

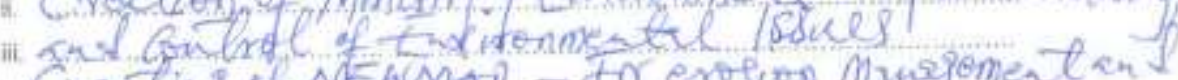

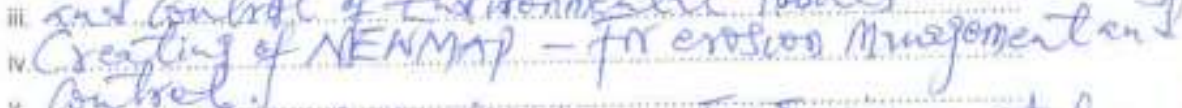

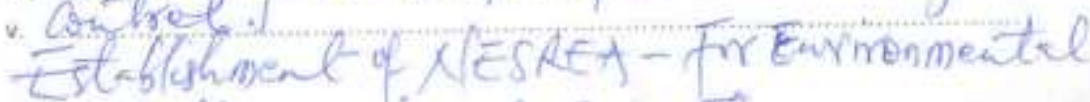
requletion and exforlement. 
2. What are the expected, outcomes of the policies? of on enforling

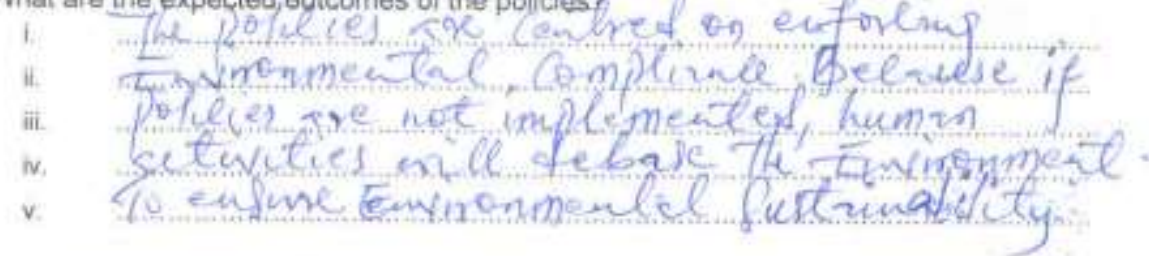

3. What structures/mechanișms have the institution put in place to achieve the policies?

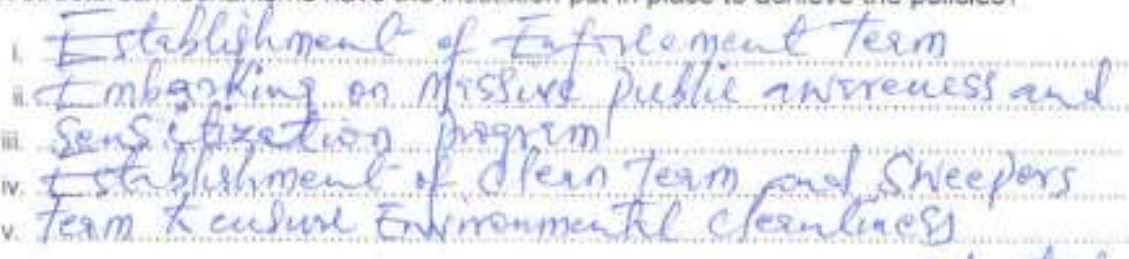

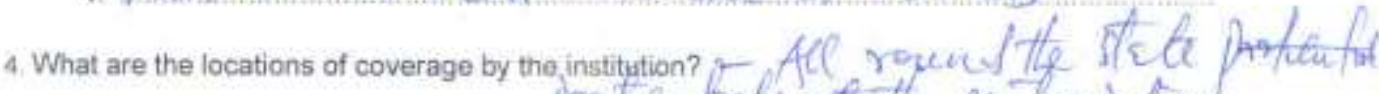

5. What are the shortcomings of the policies?

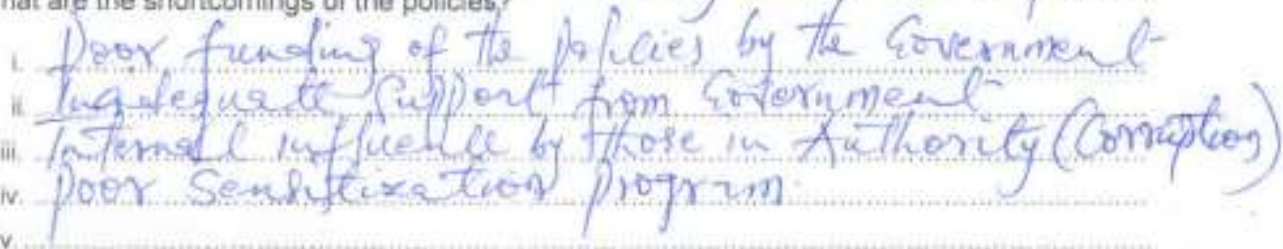

6. What challenges does the institution encounter in order to achieve the policies?

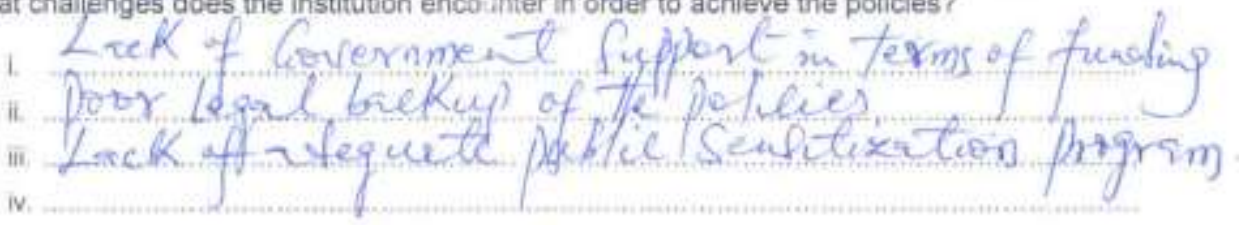

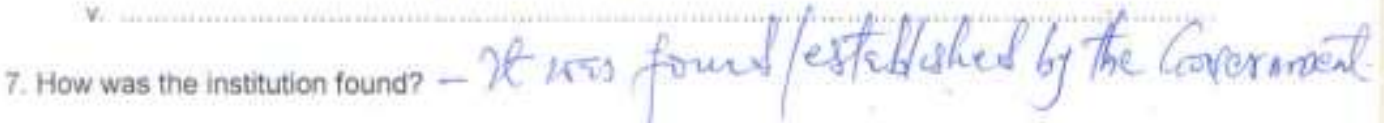
SECTION D: Shortcornings of the policies and constrains to the performance of institution for environmental management.

\begin{tabular}{|l|l|l|l|l|}
\hline & SA & A & D & SD \\
\hline Limitations of legal frame work & $\checkmark$ & & & \\
\hline Institutional bottleneck & & $\checkmark$ & & \\
\hline Corruption & & & & \\
\hline Inadequacy of Environmental Impact Assessment & & $\checkmark$ & & \\
\hline Inadequacy of funding & & & & \\
\hline Ignorance & & $\checkmark$ & & \\
\hline
\end{tabular}

Others specify 
International Journal of Research in Agriculture, Biology \& Environment (ijagri), Vol. 2 (4), Oct -Dec - 2021

Section A: Personal Data.

Please tick in $(v)$ the appropriate column that gives true information about you

Sex: Male

Female

Marital Status: Single

Married

Age: Below 20 yrs

$21-41$

$42-65$

Occupation: Traders

Farmers

Workers $\square$ Students

others

Academic level: Primary

Secondary

Degree

$\square$ Postgraduate $\square$

No formal education

Religion: Christianity

$\square$

Length of service: 0 - 1

Muslim

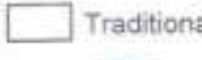

$1-2$

$6-7$

Section B: Environmental Problems in the state.

$\mathrm{SA}=$ Strongly Agree
$\mathrm{A}=$ Agree
$\mathrm{D}=$ Disagree
$\mathrm{SO}=$ Strongly Disagree

(please, tick (V) as many as are applicable

\begin{tabular}{|l|l|l|l|l|}
\hline Environmental problems & SA & A & D & SD \\
\hline Air pollution & V & & & \\
\hline Indiscriminate dumping of refuse & & & & \\
\hline overcrowding & & & & \\
\hline Poor urban housing & & & & \\
\hline Noise pollution & & & & \\
\hline Water pollution & & & & \\
\hline Land/Soll pollution & & & & \\
\hline Biodiversity loss & & & & \\
\hline Deforestation & & & & \\
\hline Erosionflood & & & & \\
\hline High density of motor & & & \\
\hline Vehicle & & & & \\
\hline
\end{tabular}

Others specify

SECTION C: Identify and describe the various policies and institutional structures/mechanisms in place for environmental management in the state

1. What policies is this institution based upon?

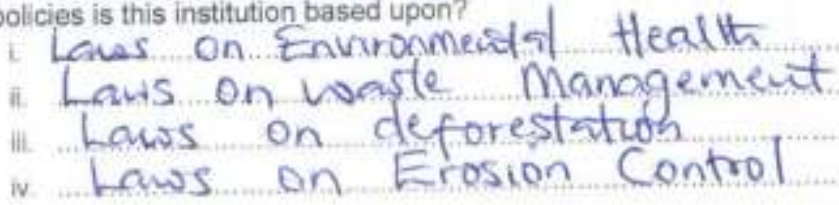

